Magdalena BOCHENEK ${ }^{1}$

\title{
NOWOCZESNE SYSTEMY RACHUNKU KOSZTÓW
}

Rachunek kosztów zawsze odgrywał istotną rolę w przedsiębiorstwie. Powszechnie używany jest do sporządzania rocznego sprawozdania finansowego. Jednak na przestrzeni lat zaczął pełnić również inne funkcje. Tradycyjne rachunki kosztów dostarczały za mało informacji potrzebnych w procesie zarządzania. Było to związane ze zmianami w preferencjach klientów, rozwojem technologii i globalizacją. Pojawiły się nowoczesne rachunki kosztów, które stały się niezbędnymi narzędziami wykorzystywanymi w zarządzaniu jednostką gospodarczą. Kadra zarządzająca może wykorzystać takie nowoczesne rachunki kosztów jak: rachunek kosztów działań, rachunek kosztów cyklu życia produktu, rachunek kosztów docelowych, rachunek kosztów jakości, rachunek kosztów ciągłego doskonalenia i wiele innych. Każda $\mathrm{z}$ tych metod musi być dostosowana do indywidualnych cech przedsiębiorstwa. Systemy te pozwalają kontrolować redukcję kosztów w jednostce i wspomagają dostosowanie produktu do potrzeb klienta. W nowoczesnych rachunkach kosztów bardzo ważne jest podejście do przedsiębiorstwa jako całości. W projekt muszą być zaangażowani wszyscy pracownicy. Zarządzający powinni wdrażać odpowiednie systemy motywacyjne dla pracowników niższego szczebla. Celem artykułu jest wskazanie znaczenia rachunku kosztów w organizacji. Wyjaśniono w nim istotę zarządzania kosztami w przedsiębiorstwie. Wymieniono również cechy nowoczesnych rachunków kosztów i dokładniej opisano trzy z nich: rachunek kosztów działań, rachunek kosztów docelowych oraz rachunek kosztów ciągłego doskonalenia. W pracy dokonano ich charakterystyki, ukazano istotę, a także wskazano ich zalety oraz wady.

Słowa kluczowe: rachunek kosztów, przedsiębiorstwo, zarządzanie.

\section{WPROWADZENIE}

Rachunki kosztów pełnią w przedsiębiorstwach bardzo ważną rolę ponieważ pozwalają między innymi na podejmowanie podstawowych decyzji związanych z działalnością jednostki i zajmują kluczowe miejsce w jej kontrolowaniu na niemal wszystkich szczeblach zarządzania. Rachunki kosztów od lat dostarczają kadrze zarządzającej informacji niezbędnych do efektywnego funkcjonowania przedsiębiorstwa, jednak dopiero pod koniec dwudziestego wieku powstała potrzeba stworzenia nowych, bardziej nowoczesnych rachunków kosztów. Było to związane między innymi ze wzrostem złożoności procesów produkcyjnych, coraz większą różnorodnością asortymentową i zwiększeniem udziału kosztów pośrednich w kosztach produkcji. W tych warunkach przedsiębiorcy zaczęli szukać takich rozwiązań, które zorientowane byłyby na realizowane procesy gospodarcze.

\footnotetext{
${ }^{1}$ Mgr Magdalena Bochenek, Zakład Finansów, Bankowości i Rachunkowości, Wydział Zarządzania, Politechnika Rzeszowska im. Ignacego Łukasiewicza, Al. Powstańców 8, 35-959 Rzeszów; e-mail: m.bochenek@prz.edu.pl.
} 
Informacje o kosztach przedstawiane są różnie w zależności od zastosowanego modelu rachunku kosztów dostosowanego do indywidualnych potrzeb odbiorców informacji. Wymogi coraz lepszego spełniania zadań przez rachunek kosztów sprawiło, że wykształciły się rozmaite modele rachunku kosztów. Powstawanie nowych oraz rozwijanie już istniejących rachunków kosztów postępuje wraz ze zamianą celów rachunku kosztów. Pierwotnie celem rachunku kosztów był pomiar kosztów głównie na potrzeby sprawozdawcze w dzisiejszych czasach przeważa orientacja na podejmowanie decyzji ekonomicznych oraz kontroli kosztów ${ }^{2}$.

Celem artykułu jest wskazanie znaczenia rachunku kosztów w organizacji, ze szczególnym uwzględnieniem tych rachunków kosztów, które stanowią odpowiedź na potrzeby zarządzających na efektywniejsze rachunki kosztów: docelowych, kaizen costing oraz działań.

\section{ISTOTA ZARZĄDZANIA KOSZTAMI}

Rachunki kosztów są ukierunkowane na pomiar kosztów związanych z prowadzeniem działalności gospodarczej. Głównym zadaniem rachunku kosztów jest dostarczanie informacji odnoszących się do kosztów wyróżnionych obiektów odniesienia kosztów. Do prawidłowego gromadzenia danych o kosztach działalności wykorzystywane są określone procedury rachunkowości, pozwalają one na systematyczne i stałe zbieranie informacji o kosztach w systemie rachunku kosztów. Tak przygotowane informacje wykorzystywane są następnie do kontroli ponoszonych kosztów i dzięki temu pozwalają zapanować nad ich poziomem. Zarządzanie kosztami ma prowadzić do osiągnięcia celu, jakim jest reedukacja kosztów działalności przedsiębiorstwa. Dotyczy działań, które są podejmowane przez kadrę zarządzającą na podstawie informacji pochodzących z systemu rachunkowości i innych źródeł. Istotą zarządzania kosztami jest wykonywanie czynności zmierzających do doskonalenia procesów gospodarczych, w szczególności do zwiększenia efektywności wykorzystania zasobów przedsiębiorstwa ${ }^{3}$.

W zależności od odbiorców informacji rachunek kosztów pełni dwa główne zadania, dostarcza informacji niezbędnych do sporządzenia sprawozdania finansowego oraz do planowania, kontroli i podejmowania decyzji w przedsiębiorstwie. W pierwszym przypadku można mówić o systematycznym rachunku kosztów, ponieważ sprawozdania finansowe przygotowywane są w stałych odstępach czasowych, a więc informacje o kosztach muszą być dostarczane regularnie. W dzisiejszych czasach dużo ważniejsze z punktu widzenia zarządzania jest druga z funkcji rachunku kosztów. Rachunek kosztów jako narzędzie zarządzania powinien dostarczyć informacji umożliwiających ${ }^{4}$ :

a) właściwy pomiar rentowności klientów oraz rentowności produktów,

b) kontrolę i planowanie kosztów,

c) poznanie przyczyn powstawania kosztów,

d) sprawne zarządzanie potencjałem przedsiębiorstwa.

W miarę zamian dotyczących kierunków wykorzystania informacji o kosztach, a także rozwoju rachunku kosztów, wykształciły się różne modele rachunku kosztów. Model rachunku kosztów to zespół procedur i zasad, zgodnie z którymi dokonuje się pomiaru kosz-

\footnotetext{
2 E. Nowak, Rachunkowość zarzadcza w przedsiębiorstwie, Warszawa 2012, s. 39-43.

3 Strategiczne zarzadzanie kosztami, red. E. Nowak, Kraków 2006, s. 15.

${ }^{4}$ Controlling kosztów i rachunkowość zarządcza, red. G.K. Świderska, Warszawa 2010, s. 25-29.
} 
tów, a informacje o kosztach są przystosowywane do specyficznych potrzeb ich użytkowników. Modele rachunku kosztów mogą mieć pewne odmiany, warianty danego modelu, które uwzględniają różne zasady przygotowania informacji o kosztach działalności ${ }^{5}$.

Rozwój nowoczesnych rachunków kosztów w Polsce następuje w znacznie wolniejszym tempie i węższym zakresie niż w praktyce państw zachodnich. Związane jest to z występowaniem gospodarki centralnie planowanej w Polsce przez długi okres czasu, przez co pojawiły się następujące czynniki spowalniające procesy implementacji nowych rachunków kosztów6:

a) mniejsze doświadczenie polskich managerów w zakresie zarządzania przedsiębiorstwami w porównaniu z praktyką managerów zachodnich,

b) sztywne struktury funkcjonalne organizacji późno sprywatyzowanych,

c) ograniczone zasoby finansowe przedsiębiorstw.

Występują również czynniki sprzyjające przyspieszeniu tempa popularności i implementacji nowoczesnych rachunków kosztów w Polsce. Są to między innymi: silna motywacja polskich managerów do podnoszenia konkurencyjności swoich przedsiębiorstw oraz stałe poszerzanie przez nich wiedzy.

\section{CHARAKTERYSTYKA POSZCZEGÓLNYCH NOWOCZESNYCH RACHUNKÓW KOSZTÓW}

Nowoczesne rachunki kosztów w dzisiejszych czasach mają coraz większe znaczenie dla zarządzania przedsiębiorstwem. Dzięki ich implementacji managerowie otrzymują informacje nowego typu, inne i bardziej dokładne niż do tej pory. Wdrażanie tego rodzaju rachunków kosztów może w przyszłości pozwolić na umocnienie pozycji przedsiębiorstwa na rynku i uzyskania przez nie przewagi konkurencyjnej. Takie rachunki kosztów wykorzystywane są głównie na potrzeby wewnętrzne jednostki, dlatego nie są ograniczone przez przepisy prawa i mogą być dostosowywane do panujących na rynku warunków, a także specyficznych cech jednostki.

\subsection{Rachunek kosztów działań (ABC)}

Rachunek kosztów działań jest metodą, która zapoczątkowana została z powodu krytyki tradycyjnego rachunku kosztów. Szukano nowych rozwiązań, które przydzielałyby koszty na produkty w sposób bardziej rzeczywisty niż dotychczas. Model ABC różni się przede wszystkim podziałem kosztów pośrednich na poszczególne produkty. Według jego zasad mogą zaistnieć warunki, w których niezbędna jest większa dokładność w estymacji kosztów (bierze pod uwagę inne czynniki kosztotwórcze niż wielkość produkcji) i w rozliczaniu kosztów na produkty (zgodnie ze zużyciem zasobów) ${ }^{7}$.

W modelu ABC zakłada się, że przyczyną powstawania kosztów są działania, dlatego kluczowe jest ich odpowiednie zidentyfikowanie. Wykonywanie działań wymaga zaangażowania zasobów, a ich zużycie związane jest z ponoszeniem kosztów. W rachunku kosztów działań niezbędne do produkcji oraz sprzedaży wyrobów są działania. Obserwuje się

\footnotetext{
5 E. Nowak, R. Piechota, M. Wierzbiński, Rachunek kosztów w zarządzaniu przedsiębiorstwem, Warszawa 2004, s. 19.

${ }^{6}$ Rachunkowość zarządcza i rachunek kosztów w systemie informacyjnym przedsiębiorstwa, red. A. Karmańska, Warszawa 2006, s. 76.

7 A. Piosik, Zasady rachunkowości zarzadczej, Warszawa 2006, s. 279-280.
} 
trend spadkowy udziału kosztów bezpośrednich w kosztach całkowitych wytwarzania produktu, a więc stale rośnie znaczenie kosztów pośrednich produkcji. Tendencja ta wiąże się ze zmianami zachodzącymi w procesach gospodarczych jednostki, np. wprowadzenie elastycznych systemów produkcyjnych, automatyzacja procesów produkcyjnych. Głównym przedmiotem zainteresowania rachunku kosztów działań, jest odpowiednie przypisanie kosztów pośrednich do produktów ${ }^{8}$.

Nie każde przedsiębiorstwo będzie osiągać dobre wyniki po wdrożeniu rachunku kosztów działań. Należy przeprowadzić wnikliwą analizę, przeszkolić pracowników i dostosować rachunek kosztów do specyficznych uwarunkować jednostki. Wdrożenie modelu ABC sprawdzi się najlepiej w przedsiębiorstwach, w których:

a) występuje skomplikowana i złożona $\mathrm{z}$ wielu asortymentów produkcja,

b) decyzje kadry zarządzającej podejmowane są bez uwzględnienia informacji kosztowych,

c) wyroby gotowe narażone są na mocną konkurencję cenową,

d) udział kosztów pośrednich w produkcji jest duży i ciągle rośnie.

Implementacja rachunku kosztów działań musi być poprzedzona odpowiednim przygotowaniem. Szczególnie ważne jest szkolenie pracowników, ponieważ do wprowadzenia tego modelu potrzeba zaangażowania całego personelu (nie tylko kierownictwa) i odpowiedniej wiedzy. Etapy kalkulacji kosztów w systemie ABC są następujące9:

a) wybór istotnych działań,

b) ustalenie kosztów poszczególnych działań,

c) określenie ośrodków poszczególnych działań,

d) rozliczenie kosztów każdego działania na produkty.

Etap pierwszy jest najważniejszy i najtrudniejszy ze wszystkich etapów kalkulacji. Poprawne zidentyfikowanie działań może zdecydować o powodzeniu całego procesu wdrożeniowego modelu ABC. Jeżeli zostanie wyróżnionych zbyt dużo działań przydatność decyzyjna tego rachunku kosztów może się zmniejszyć, a także będzie trudniej go zaimplementować. W literaturze można spotkać się z optymalną ilością działań w liczbie od dziesięciu do dwudziestu. Te liczby są jednak przykładowe, mogą się wahać w zależności od uznania ich przydatności przez zespół wdrożeniowy.

W drugim etapie następuje określenie kosztów dla danego działania. W tradycyjnym rachunku kosztów ośrodki kosztów wydziałowych stosowano głównie do przetrzymania kosztów pośrednich i ogólnych, do czasu aż nie zostaną rozdzielone do ośrodków kosztów na poziomie produkcji. W koncepcji ABC utrzymywanie pośrednich kosztów wiąże się ze zorganizowaniem ośrodków kosztów działań, są w nich gromadzone odpowiednie koszty, aż do momentu przypisania ich do produktów. W rachunku kosztów działań koszty można przypisywać do działań w sposób pośredni lub bezpośredni. Zaleca się w miarę możliwości stosowanie metody bezpośredniego obciążania ośrodków kosztów działań kosztami różnego rodzaju np. kosztami płac pracowników ${ }^{10}$.

Etap trzeci obejmuje określenie nośników kosztów dla działań. Nośnik kosztów można zdefiniować jako ilościowy wskaźnik głównego obciążenia roboczego poszczególnych działań. W modelu ABC nośniki kosztów powinny być stosunkowo niedrogie i proste, a także możliwe do określenia dla zamówień klientów, konkretnego produktu lub grupy

8 E. Nowak, Zaawansowana rachunkowość zarzadcza, Warszawa 2009, s. 224.

9 J.J. Glynn, J. Perrin, M.P. Murphy, Rachunkowość dla menedżerów, Warszawa 2003, s. 320-323.

${ }^{10}$ Ibidem, s. 532. 
produktów. Przykładowo dla działania „,zakup materiałów” nośnikiem może być liczba zamówień, otrzymanych faktur lub dostaw. Wielkość, która zostaje przyjęta jako nośnik dla danego działania powinna ${ }^{11}$ :

a) być zrozumiała i łatwo mierzalna,

b) odzwierciedlać przyczyny powstawania kosztów,

c) wyrażać zapotrzebowanie określonego produktu, w odniesieniu do pozostałych wyrobów, na poszczególne działania.

Ostatnim etapem kalkulacji jest przypisanie kosztów działań na poszczególne działania. Można to zrobić na różne sposoby. Aby ustalić jednostkowy koszt produktów trzeba obliczyć kilka wartości, mogą one być określone wzorami.

Rachunek kosztów działań musi być nieustanie uaktualniany, a jego wdrożenie jest kosztowne i wymaga zaangażowania całego przedsiębiorstwa. Mimo to może przynieść jednostce wiele korzyści i posiada wiele zalet, są to:

a) dostarczanie przydatnych mierników działalności,

b) staranne i adekwatne wykazanie kosztów produktów

c) nacisk na duże zróżnicowanie nowoczesnej produkcji,

d) realistycznie ujęty łańcuch kosztów,

e) innowacyjność w badaniu planowania, budżetowania oraz dynamiki kosztów poprzez analizę czynników kosztotwórczych,

f) dokładne wykazanie działań oraz zwrócenie uwagi na realne pochodzenie kosztów,

g) przydzielenie kosztów na różne obiekty kalkulacji tj. obszary odpowiedzialności, procesy, produkty, klientów,

h) szczegółowa analiza przyczyn występowania kosztów stałych.

\subsection{Model target costing oraz kaizen costing}

Rachunek kosztów docelowych (target costing) i rachunek kosztów ciągłego doskonalenia dla osiągnięcia lepszych wyników często stosowane są razem. Koncepcje te wywodzą się z kultury japońskiej, z tego powodu w Europie ich implementacja nie jest łatwa.

Rachunek kosztów docelowych usprawnia zarządzanie kosztami usług i wyrobów gotowych w fazie ich projektowania. Uważa się, że jest to efektywne narzędzie rachunkowości zarządczej, ponieważ około 80-90\% kosztów danego produktu przesądzone jest już na etapie jego planowania i projektowania. Metoda target costing może być wykorzystywana zarówno przy tworzeniu strategii wejścia na rynek całkowicie nowego produktu, a także produktu już istniejącego. Ten rachunek kosztów służy głównie wczesnemu kształtowaniu się struktury i poziomu kosztów produkcji wyrobów gotowych jeszcze przed uruchomieniem produkcji. Już w tym początkowym etapie obejmuje analizę kształtowania się kosztów produktu w trakcie jego całego cyklu życia z jednoczesnym zapewnieniem realizacji oczekiwań klientów ${ }^{12}$.

W rachunku kosztów docelowych można wyodrębnić cztery główne etapy ${ }^{13}$ :

a) wyznaczenie docelowej ceny,

b) ustalenie docelowego zysku,

c) wyznaczenie dopuszczalnego kosztu,

d) ustalenie docelowego kosztu.

${ }^{11}$ D. Dobija, M. Kucharczyk, Rachunkowość zarządcza, Warszawa 2009, s. 252.

${ }^{12}$ B. Zyznarska-Dworczak, Jak zarzadzać kosztami w przedsiębiorstwie, Warszawa 2012, s. 76.

${ }^{13}$ P. Szczypa, Rachunkowość zarządcza - klucz do sukcesu, Warszawa 2014, s. 106. 
W etapie pierwszym następuje ustalenie docelowej ceny, która jest ceną sprzedaży danego produktu możliwą do uzyskania na rynku. Powinna być ona ustalana przez kierownictwo na podstawie badań rynku i przy uwzględnieniu między innymi: klientów, stopnia rozwoju rynku, przewidywanego popytu i potencjalnej konkurencji.

Jednostkowy docelowy zysk przedsiębiorstwo może ustalić na podstawie docelowej ceny i przewidywanej wielkości sprzedaży. Zysk docelowy powinien pozwolić na osiągnięcie założonej rentowności sprzedaży.

Na postawie wielkości wyznaczonych w etapie pierwszym i drugim ustalana jest wartość kosztu dopuszczalnego, który ma zagwarantować wygenerowanie założonego zysku jednostkowego. Koszt dopuszczalny to najwyższy poziom kosztu jednostkowego wyrobu gotowego.

Ostatni etap obejmuje wyznaczenie kosztu docelowego. Koszt docelowy nie może mieć wyższej wartości niż koszt dopuszczalny. Przy wyznaczaniu tej wielkości należy wziąć pod uwagę wszystkie uwarunkowania dotyczące wytwarzania danego produktu. Należy więc wyznaczyć bieżący koszt wytworzenia. W przypadku, gdy koszt bieżący będzie mniejszy od kosztu dopuszczalnego można podjąć decyzję o wprowadzeniu produktu na rynek. Natomiast, gdy koszt bieżący będzie przewyższał poziom kosztu dopuszczalnego przedsiębiorstwo powinno zrezygnować z produkcji danego wyrobu lub zaakceptować niższy poziom stopy zysku.

Idea metody target costing przenika wszystkie fazy występujące w łańcuchu tworzenia wartości: od finalnego producenta do przedsiębiorstwa występującego na ostatnim miejscu w łańcuchu dostaw. Ukształtowanie produktów w sposób prawidłowy pod względem jakościowym i funkcjonalnym wymaga zaangażowania dostawców w proces ich projektowania. Najczęściej odbywa się to poprzez zaangażowanie technologów, inżynierów oraz innych specjalistów w prace wykonywane u producenta finalnego. Bardziej ścisłe relacje producenta $\mathrm{z}$ dostawcami służą lepszemu zaspokajaniu potrzeb odbiorców końcowych ${ }^{14}$.

$\mathrm{W}$ połączeniu z metodą target costing, często używa się rachunku kosztów ciągłego doskonalenia (kaizen costing). Kaizen costing to koncepcja mająca na celu nieustanne usprawnianie, udoskonalanie związane z organizacją pracy i procesami technologicznymi. W tym rachunku kosztów ważne jest osiągnięcie większej efektywności procesów wytwarzania usług i produkcji wyrobów gotowych. Całe przedsiębiorstwo (kierownictwo oraz pracownicy) stara się znaleźć sposoby na redukcję kosztów związanych z wytwarzaniem i dostarczaniem produktów. W tym rachunku kosztów ważne jest założenie sobie realnych celów i systematyczne dążenie do ich zrealizowania. Kluczowy jest również system motywacyjny pracowników, który przeprowadzony odpowiednio ma tworzyć nie tylko dobrą atmosferę, ale przede wszystkim zwiększyć zaangażowanie pracowników w wykonywane zadania $^{15}$.

\section{ZAKOŃCZENIE}

Odpowiednie zarządzanie przedsiębiorstwem, przy obecnym poziomie konkurencji na rynku, jest kluczowe w osiągnięciu sukcesu. Kierownictwo posiada wiele możliwości i narzędzi zarządzania, których powstaje coraz więcej. Nowoczesne rachunki kosztów to metody, które mogą usprawnić działanie organizacji i pozwolić na redukcję kosztów, a tym

\footnotetext{
${ }^{14}$ E. Nowak, R. Piechota, M. Wierzbiński, Rachunek..., op. cit., s. 148-149.

${ }^{15}$ J. Świderski, Rachunek kosztów, Warszawa 2011, s. 91.
} 
samym generowanie większych zysków. Aby tak się stało zarządzający muszą zdobyć wiedzę na ich temat i wybrać dla przedsiębiorstwa taki rachunek kosztów, który pozwoli na uzyskanie najlepszych efektów.

Wykorzystanie nowoczesnych rachunków kosztów nie tylko pozwala na redukcję kosztów w jednostce, ale również wychodzi naprzeciw oczekiwaniom klientów. W nowoczesnym przedsiębiorstwie to klient jest najważniejszy, ponieważ dzięki niemu generowane są przychody. Inne jest także spojrzenie na przedsiębiorstwo, ponieważ w tych metodach pracownicy niższego szczebla są równie ważni jak kierownictwo. Koncepcje te integrują wszystkich pracowników i motywują ich do zaangażowania w projekty.

Przedsiębiorstwa są odmienne pod wieloma względami, a główna różnica dotyczy ludzi wewnątrz, a więc pracowników. Z tego powodu każda jednostka powinna podejść do zarządzania indywidualnie. Nowoczesne rachunki kosztów nie są tak sformalizowane jak tradycyjne, dzięki czemu mogą być dostosowywane do panujących warunków i modyfikowane w dowolny, wygodny dla kierownictwa sposób.

\section{LITERATURA}

[1] Controlling kosztów i rachunkowość zarządcza, red. G.K. Świderska, Difin, Warszawa 2010.

[2] Dobija D., Kucharczyk M., Rachunkowość zarzadcza, Wydawnictwo Akademickie i Profesjonalne, Warszawa 2009.

[3] Glynn J.J., Perrin J., Murphy M.P., Rachunkowość dla menedżerów, Wydawnictwo Naukowe PWN, Warszawa 2003.

[4] Nowak E., Rachunkowość zarządcza w przedsiębiorstwie, CeDeWu, Warszawa 2012.

[5] Nowak E., Zaawansowana rachunkowość zarzadcza, Polskie Wydawnictwo Ekonomiczne, Warszawa 2009.

[6] Nowak E., Piechota R., Wierzbiński M., Rachunek kosztów w zarządzaniu przedsiębiorstwem, Polskie Wydawnictwo Ekonomiczne, Warszawa 2004.

[7] Piosik A., Zasady rachunkowości zarządczej, Wydawnictwo Naukowe PWN, Warszawa 2006.

[8] Rachunkowość zarządcza i rachunek kosztów w systemie informacyjnym przedsiębiorstwa, red. A. Karmańska, Difin, Warszawa 2006.

[9] Strategiczne zarządzanie kosztami, red. E. Nowak, Oficyna Ekonomiczna, Kraków 2006.

[10] Szczypa P., Rachunkowość zarzadcza - klucz do sukcesu, CeDeWu, Warszawa 2014.

[11] Świderski J., Rachunek kosztów, Oficyna Wydawnicza WSEiZ w Warszawie, Warszawa 2011.

[12] Zyznarska-Dworczak B., Jak zarządzać kosztami w przedsiębiorstwie, Difin, Warszawa 2012.

\section{MODERN COST ACCOUNTING}

Cost accounting had always been important for an enterprise. It is commonly used for preparing annual financial statements. Over the years, it began to perform other functions. Traditional cost accounts provided insufficient information needed in the management process. It was related with changes in consumer's preferences, development of technology and globalization. Modern cost accounts have emerged and have become indispensable in managing an enterprise. Management can use such cost accounts as activity based costing, life cycle cost 
analysis, target costing, quality costs calculation, kaizen costing and many others. Each of these methods must be tailored to the individual characteristics of the business. These systems support cost control and help to match the product to the needs of the customer. In modern cost accounts it is important to approach the company as a whole. All employees must be involved in the project. Managers should implement appropriate incentive programs for employees. The thesis is concerned with the importance of cost accounting in a business enterprise. In addition, it explains the essence of cost management in the enterprise. It also shows the features of modern cost accounting and describes in detail three of them: activity based costing, target costing and kaizen costing. The paper deals with essence of these methods and points out their advantages and disadvantages.

Keywords: cost accounting, enterprise, management.

DOI: $10.7862 /$ rz.2017.hss.64

Przestano do redakcji: luty $2017 \mathrm{r}$. Przyjęto do druku: grudzień 2017 r. 